Man and Nature

L'homme et la nature

\title{
"Those Scotch Imposters and their Cabal": Ossian and the Scottish Enlightenment
}

\section{Richard B. Sher}

Volume 1, 1982

URI : https://id.erudit.org/iderudit/1011791ar

DOI : https://doi.org/10.7202/1011791ar

Aller au sommaire du numéro

Éditeur(s)

Canadian Society for Eighteenth-Century Studies / Société canadienne d'étude du dix-huitième siècle

ISSN

0824-3298 (imprimé)

1927-8810 (numérique)

Découvrir la revue

Citer cet article

Sher, R. B. (1982). "Those Scotch Imposters and their Cabal": Ossian and the Scottish Enlightenment. Man and Nature / L'homme et la nature, 1, 55-63. https://doi.org/10.7202/1011791ar

Copyright (c) Canadian Society for Eighteenth-Century Studies / Sociéte canadienne d'étude du dix-huitième siècle, 1982
Ce document est protégé par la loi sur le droit d'auteur. L'utilisation des services d'Érudit (y compris la reproduction) est assujettie à sa politique d'utilisation que vous pouvez consulter en ligne.

https://apropos.erudit.org/fr/usagers/politique-dutilisation/ 


\section{6. "Those Scotch Imposters and their Cabal": Ossian and the Scottish Enlightenment}

Many a voice and many a harp, in tuneful sounds arose. Of Fingal's noble deeds they sung; of Fingal's noble race: And sometimes, on the lovely sound, was heard the name of Ossian.

James Macpherson's Fingal (1761)

Although the name of Ossian was heard a great deal during the late eighteenth and early nineteenth centuries, it has since become little more than a historical curiosity. We are amazed and amused that so many intelligent, well-educated people could have sincerely believed that the works of Ossian were both completely authentic and (what is perhaps more astounding) aesthetically unsurpassed - even by Homer. ' We have become accustomed to regarding this strange phenomenon as a case of deliberate deception: the public was simply fooled by James Macpherson, a brash young Highlander who cleverly tricked the literary world into accepting compositions that were in part distortions of genuine Gaelic poems and ballads, in part his own creation, as the original poetry of a legendary thirdcentury Highland bard called Ossian. The world of letters fell for the ruse, so the story goes, because Macpherson was shrewd enough to endow his Ossianic poetry with the primitivism and pathos for which a vast audience of preromantics yearned. Ossian was Homer cleaned up for eighteenth-century tastes and then sold to an unsuspecting public by an unscrupulous entrepreneur. ${ }^{2}$

This literary "confidence-man" explanation for the genesis and vogue of Ossian is not exactly false, but neither is it entirely true. For one thing, while Macpherson alone produced the Ossianic "translations" themselves, in a very real sense his Ossian was also the product of a "cabal" of Edinburgh literary men who provided the necessary inspiration, incentive, financial support, editorial assistance, publishing connections, and emotional encouragement. At the heart of this Ossianic "cabal" stood a coterie of Presbyterian clergymen affiliated with the Moderate party in the Church of Scotland John Home, Hugh Blair, Adam Ferguson, William Robertson, and Alexander Carlyle - but these "Moderate literati" were at various times assisted by other Scottish literati and gentlemen, the most important of whom seem to have been Robert Chalmers and Patrick Murray, Lord Elibank. 
Furthermore, the sentimental, pre-romantic, primitivist component in Ossianic poetry, while very possibly the most important factor in accounting for the success of Ossian abroad, was only one of several features that made Ossianic poetry so attractive to the Edinburgh "cabal." It is to other, peculiarly Scottish factors that we must turn in order to understand how and why Ossian came to be.

Our account begins in the critical year 1757, shortly before Macpherson introduced Ossian to the Scottish literary community. In July of that year, when David Hume made his famous boast about the Scots being "the People most distinguish'd for Literature in Europe." ${ }^{3}$ the literati of Edinburgh were experiencing a sense of national pride and expectation difficult for us to grasp fully today. The Select Society was in full bloom. ${ }^{4}$ There was much talk of "improvement." Attempts to censure Hume and Kames in the General Assembly of the church had been decisively defeated by the Moderate party. John Home's Douglas and William Wilkie's Epigoniad had just proven - at least to the satisfaction of Edinburgh literary men like Hume - that Scotsmen could write first-rate tragedies and epic poems, and several other young Scottish authors, such as Adam Smith, William Robertson, and Adam Ferguson, were soon to publish works of history and philosophy that would give Scotland an enduring name in the republic of letters. There was a growing sense among the cultural elite of Edinburgh that Scotland was on the verge of a new era of civilization and enlightenment which would compel Englishmen to forget past differences and to embrace their northern neighbors as equal partners in a truly united kingdom. The outbreak of the Seven Years War in the previous year had encouraged this spirit of British unity by pitting the Scots and English against a common enemy. ${ }^{5}$ In a significant speech in Home's Douglas, Lady Randolph articulated the view that England and Scotland were like two foolish sisters who habitually waste their energies fighting each other instead of joining forces against "foreign foes":

A river here, there an ideal line,

By fancy drawn, divides the sister kingdoms.

On each side dwells a people similar,

As twins are to each other; valiant both;

Both for their valour famous thro' the world.

Yet will they not unite their kindred arms,

And, if they must have war, wage distant war,

But with each other fight in cruel conflict. ${ }^{6}$

After half a century of animosity and prejudice it appeared that the time had finally come to "compleat the Union."

Two issues that came to a head in the first half of 1757 demonstrated that Scottish dreams of obtaining political and literary equality in English eyes were not soon to be realized. First, Scotland was excluded by Parliament from the provisions of Pitt's militia bill, ostensibly because of English fears that Scotland would be unable to finance a militia but probably more because of English fears about the danger of arming potential Jacobites, as the Scots were widely perceived to be. To loyal Whigs like the Moderate literati of 
Edinburgh, who had fought and preached against the Jacobite menace posed by Bonnie Prince Charlie twelve years earlier, this was a devastating blow not only to Scottish pride but also to Scottish defense. The feeling of vulnerability which had so upset these men during the Forty-Five returned, only this time the immediate threat came from France rather than the Highlands. When a French squadron under Admiral Thurot headed for the North Sea late in 1759 and then actually appeared in Scottish waters early in 1760, Presbyterian Whigs like William Robertson joined with Jacobites like Lord Elibank in proclaiming the militia question the most important issue since the Union. ${ }^{8}$ Yet efforts to extend the provisions of the English militia act to Scotland were handily defeated in the House of Commons in April 1760. ${ }^{9}$

The second instance of Anglo-Scottish tension was literary rather than political. It was thought to be bad enough that Home's Douglas had been rejected as "unfit for $y^{\mathbf{e}}$ Stage" by London's leading actor and theatrical manager, David Garrick. ${ }^{10}$ What rankled the Scottish literati still more was the fact that even after Douglas had triumphed gloriously in Edinburgh in December 1756 and then enjoyed a successful run at London's Covent Gardens three months later, some English literary critics, including Samuel Johnson, refused to recognize Home's tragic genius. The same pattern occurred when Wilkie's Epigoniad put the Scottish literary world "in raptures" during the spring of $1757,{ }^{11}$ only to be either panned or ignored by English critics. The following winter Home's second play, Agis, was savagely attacked as a mere party piece - the party being that of Pitt, Bute, and Leicester House that was then associated with the cause of martial virtue ${ }^{12}-$ and in 1759 a London edition of Wilkie's Epigoniad failed miserably despite the efforts of David Hume to make it less offensive to English readers. ${ }^{13}$

Thus, even before the Earl of Bute's rise to political power in the early 1760s touched off the century's biggest outburst of anti-Scottish sentiment in England, Scottish men of letters were feeling bitterly resentful towards John Bull for denying Scotland her due in military and literary affairs. The Bute era seriously intensified that resentment, especially since Bute himself was so closely connected with the Scottish literati as personal and literary patron. Meanwhile the Scots militia agitation continued, and early in 1762 the Moderate literati, Elibank, and other members of the Edinburgh literary community established the Poker Club for the express purpose of stirring up support for a Scots militia. As in 1760, however, the Scots militia scheme had little political support in England, and in March 1762 Bute and the Scottish members of Parliament decided to shelve a Scots militia bill rather than incur another humiliating defeat in the Commons.

It is surely no accident that the same Edinburgh literati who took the lead in the cause of Scottish literary nationalism, spearheaded the Scots militia campaigns of 1759-60 and 1762, and established the closest relations with the Earl of Bute were the very men who encouraged - one might almost say commissioned - the Ossianic endeavors of James Macpherson. In 1759 Macpherson was an obscure young poet working as tutor to the son of a Highland laird. His first contact with the Edinburgh literati may have been with Adam Ferguson, a fellow-Highlander who is said to have supplied him with a letter of introduction to John Home. ${ }^{14}$ At the resort town of Moffat, in 
early autumn 1759, Home met Macpherson, saw several of his Ossianic fragments in English "translation," and showed them to Alexander Carlyle and another Moderate clergyman, Rev. George Laurie of Loudon. Home and Carlyle then carried their "precious discovery" to Blair, Robertson, and Elibank, and in June 1760 these literary men published at Edinburgh a modest collection of fifteen of Macpherson's little Ossianic poems under the title Fragments of Ancient Poetry, collected in the Highlands of Scotland, with an anonymous preface by Hugh Blair. ${ }^{15}$

Two crucial factors should be noted in regard to the events leading to publication of Macpherson's Fragments. First, we must be aware that when Ferguson, Home, and Carlyle met Macpherson in 1759 they were obsessed with fear about Scotland's vulnerability in the event of a French invasion and resentment towards England for making such a situation possible. Shortly before his critical meeting with Macpherson at Moffat, Home articulated this theme in a characteristically vehement letter to Lord Bute:

I am sorry to say My Lord that this country is in the most wretched situation that ever any country was in which the people were allowed to talk of Liberty. The ignorance of the English and I don't [know] what name to give to the conduct of the Scotch has reduced us in the midst of alarms, to a state totally defenceless. No Poet that ever foamed with inspiration can express the grief and indignation of those Scots that still love their country, to find themselves disarmed. ${ }^{16}$

The same obsession characterizes much of the extant correspondence from this period of Ferguson, Carlyle, Elibank, and Robertson, Indeed, Ferguson was only half joking when he told Gilbert Elliot in September 1759 that he and Home actually hoped for a French invasion in order to horrify people into realizing the need for a Scots militia! ${ }^{17}$ The attraction of Macpherson's Ossianic Fragments to these Edinburgh literary men seems to have derived largely from its depiction of a race of heroic Scottish warriors that formed an obvious contrast with their disarmed and sometimes indifferent descendants of the eighteenth century. ${ }^{18}$ This militaristic aspect was made all the more appealing because it was sheathed in the polite veneer of sentimental neo-classicism. Here were poems that spoke of noble deeds but little bloodshed, rude manners mixed with lofty sentiments, much weeping and dying but no physical pain. Here, too, were poems with a pedigree, and a pedigree far older than anything the English could produce. English critics could sneer and scoff at Home's tragedies and Wilkie's Epigoniad, but could they possibly deny the importance of an authentic third-century Highland bard? In short, Macpherson's Ossianic Fragments served Home and his friends both in their ongoing propaganda war against John Bull for recognition of Scotland's literary accomplishments and in their program to encourage martial virtue and a Scots militia.

Secondly, we must realize just how passive Macpherson was in the events leading to publication of the Fragments. He did not come to Edinburgh with grandiose claims of a major discovery. On the contrary, he was "entreated and dragged" into the project, as Hugh Blair reminded a skeptical David 
Hume some years later. ${ }^{19}$ John Home had actually been looking for examples of ancient Gaelic poetry long before his visit to Moffat, and it was only "with some difficulty" that he had prevailed upon young Macpherson to provide him with several short specimens in English translation. The idea to publish a collection of Macpherson's Ossianic fragments had originated with Hugh Blair, and "much and repeated importunity" had been required before Macpherson would agree to it. ${ }^{20}$ Blair had secured a publisher and written an enthusiastic preface. Even the style of the fragments had probably been suggested to Macpherson by his Edinburgh backers, for it seems more than likely that they were the unnamed persons whom Macpherson later credited with persuading him to render Ossian in "what is called a prose version" instead of verse. ${ }^{21}$

The factors and individuals that were chiefly responsible for the Fragments of Ancient Poetry were also the driving forces behind Macpherson's later and better known Ossianic endeavors, Fingal (1761) and Temora (1763), only the scale of the enterprise was enlarged and the stakes increased. After the success of the Fragments, Macpherson displayed his usual reluctance to participate in any further Ossianic exertions and once again had to be "entreated and dragged" into action by the Edinburgh literary "cabal." This time Blair organized a special dinner party in Macpherson's honor, to which Robertson, Elibank, Home, Sir Adam Fergusson and others came for the specific purpose of persuading Macpherson to undertake a Highland jaunt in search of an epic about the heroic exploits of Ossian's father, an ancient Scottish king called Fingal. ${ }^{22}$ Since Macpherson's meager income as a tutor could not provide the necessary funds for such a jaunt, Blair also organized a systematic collection (under the supervision of Robert Chalmers) which is said to have raised $£ 100$ for the Ossianic cause. ${ }^{23}$ We must imagine a poor, proud, previously unknown young Highland lad being feted and funded by some of Edinburgh's leading literary figures and men of affairs. The pressure to comply with their wishes must have been enormous, certainly more than Macpherson could withstand. Considering these circumstances, the notion of a slick confidence man singlehandedly hoodwinking the Edinburgh literati begins to appear untenable. It would be closer to the truth to say that Macpherson was as much the victim as the victimizer of the Edinburgh literary community.

Macpherson was smart enough to know what was expected of him. The initial Ossianic fragments had been a source of great pride to Edinburgh literary men, but only a complete Gaelic epic, dressed, of course, in neoclassical English garb, could possess the scope and grandeur necessary to elevate Scotland to a new place in the national history of poetry. It is significant that long before Macpherson had even begun to search for Fingal and Temora Blair was privately referring to those works as "our epics." ${ }^{24}$ After Macpherson returned from his first Highland excursion early in 1761, Blair kept a watchful eye on his "translating" progress; Robert Chalmers escorted him to London to secure a publisher there; John Home accompanied him on a second Highland jaunt in the spring and summer of 1761; and Lord Bute was persuaded to become Ossian's foremost patron. By the time Fingal actually appeared, the Edinburgh literary "cabal" had invested far too much time and energy in the project to tolerate much skepticism about Ossian's 
authenticity, and they angrily attributed such skepticism to the anti-Scottish prejudices and machinations of the English. "Who but John Bull could entertain the belief of an imposture so incredible as this?", Blair asked David Hume with undisguised hostility in $1763 .{ }^{25}$ Yet testimony submitted to the Highland Society indicates that Blair, Carlyle, and Ferguson suspected all along that Macpherson had taken "liberties" in piecing together "separate or broken fragments" to create his Ossianic epics. Those epics were apparently considered too important for nationalistic reasons to be discredited simply because they had never really existed! ${ }^{26}$

Scottish literary nationalism was not the only cause for which Fingal's sharp sword did strike. By bravely performing his duty as king and warrior in a world of continual adversity, by fighting only for public virtue, and above all by successfully defending Scotland against armies of foreign invaders, ${ }^{27}$ Fingal raised to epic proportions the theme of martial virtue in the service of national defense that had been suggested in a fragmentary way by Macpherson's first book of Ossianic poetry. By contemporary standards Fingal's forces were in fact nothing but a "Raw Militia" - as Alexander Carlyle later termed the army of Highlanders that had beaten Cope's regulars at Prestonpans in $1745^{28}$ - and it seems likely that Fingal was read by its Scottish patrons as a pro-militia statement. How else can we explain the fact that the men who formed the nucleus of the Edinburgh "cabal" responsible for Fingal also constituted the nucleus of the Poker Club, which came into existence within weeks of Fingal's publication for the purpose of spreading Scots militia propaganda? ${ }^{29}$ Elibank, Carlyle, and Ferguson (who gave the club its name) head the Poker's membership list, and Home, Robertson, and Blair were also early members. The only other man known to have attended the important Ossianic dinner party of June 1760, Sir Adam Fergusson, was a member, as was Robert Chalmers, the Edinburgh merchant who directed the Ossianic collection drive and accompanied Macpherson to London to secure a publisher for Fingal. Attendance figures for the period 1774-1784 show that Home, Ferguson, Robertson, Carlyle, Blair, and Elibank (until his death in 1778) continued to be among the club's most active participants, and Robert Chalmers attended more meetings during those years than any other member. ${ }^{30}$

Hostile contemporary English critics like Samuel Johnson and Horace Walpole employed such phrases as "those Scotch imposters and their cabal" (Walpole) and "Scotch conspiracy in national falsehood" (Johnson) when privately discussing the Ossian affair. ${ }^{31}$ This line of thought would seem to suggest that those contemporary English critics were closer to the truth than they themselves could have known. Ossian was a group effort on the part of James Macpherson and a "cabal" of Edinburgh literati who were motivated, largely by topical issues which were in turn situated within the broader context of Scottish aspirations and disappointments in relations with England during the era of the Seven Years War and the political "reign" of the third Earl of Bute.

Such considerations do not render Ossian any less fraudulent, but they do suggest a new view of Macpherson's personality and role in the Ossian affair. Beneath his cocksure exterior, Macpherson now appears to have been an 
insecure young man who found himself pushed along by the leaders of the Edinburgh literary community, whom he greatly admired and did not wish to disappoint. ${ }^{32} \mathrm{He}$ perceived what they were after and was manipulated by them into producing it. Far from being merely a "confidence man", he was himself conned into playing a game whose rules and stakes he probably never completely understood until play had already begun. By that time his only alternatives were failure or fraudulence. After some hesitation he opted for the latter and never looked back.

\author{
Richard B. Sher \\ New Jersey Institute of Technology
}

\title{
Notes
}

' John Gordon, Occasional Thoughts on the Study and Character of Classical Authors, on the Course of Literature, and the present Plan of a Learned Education. With some Incidental Comparisons between Homer and Ossian (London, 1762), pp. 90-130; S.N. Cristea, "Ossian v. Homer: An Eighteenth-Century Controversy," Italian Studies 24 (1969), 93-111.

2 The classic indictment of Macpherson is Malcolm Laing's edition of The Poems of Ossian, containing the Poetical Works of James Macpherson, 2 vols. (Edinburgh, 1805). The revival of serious Gaelic scholarship toward the end of the nineteenth century fostered more sophisticated critiques which dropped Laing's emphasis on plagiarism from classical and English sources in favor of detailed demonstrations of the manner in which Macpherson misused Gaelic materials: Alexander Macbain, "Macpherson's Ossian," The Celtic Magazine 12 (February, March, and April 1887), 145-54, 193-201, 241-54; Alfred Nutt, Ossian and the Ossianic Literature (London, 1899). These works laid the foundation for J.S. Smart's standard account of the entire Ossian affair, James Macpherson: An Episode in Literature (London, 1905), which is little more than a sustained polemic against its subject. Bailey Saunders, The Life and Letters of James Macpherson (London, 1894) and Derick S. Thomson, The Gaelic Sources of Macpherson's "Ossian" (Edinburgh, 1951) are somewhat more sympathetic. That the pre- romantic and primitivist strain in Ossian constitutes the key to its extraordinary success has been maintained in virtually every piece of Ossianic criticism since Hugh Blair's Critical Dissertation on the Poems of Ossian, the Son of Fingal (London, 1763). For a particularly perceptive discussion along these lines, see John L. Greenway, "The Gateway to Innocence: Ossian and the Nordic Bard as Myth," in Studies in Eighteenth-Century Culture, vol. 4, ed. Harold E. Pagliaro (Madison, Wisc., 1975), pp. 161-70.

${ }^{3}$ Hume to Gilbert Elliot, 2 July 1757, in The Letters of David Hume, ed. J.Y.T. Greig, (Oxford, 1932), I, 255.

${ }^{4}$ Roger L. Emerson, "The Social Composition of Enlightened Scotland: The Select Society of Edinburgh, 1754-1764," Studies on Voltaire and the Eighteenth Century 114 (1973), 291-329.

"On the importance of the Seven Years War for the emergence of a sense of "Britishness" in Scotland, see Alexander Murdoch, "The People Above": Politics and Administration in MidEighteenth-Century Scotland (Edinburgh, 1980), chap. 4.

${ }^{6}$ John Home, Douglas, ed. Gerald D. Parker (Edinburgh, 1972), act 1, lines 125-33.

The significance of this popular contemporary phrase is discussed by Rosalind Mitchison in "Patriotism and National Identity in Eighteenth-Century Scotland," in Nationality and the Pursuit of National Independence, ed. T.W. Moody (Belfast, 1978), pp. 73-95.

${ }^{8}$ Elibank to Charles Townshend, 21 December 1759, and Robertson to Townshend, 23 February 1760, Townshend Papers, William L. Clements Library, Univ. of Michigan, GD 224/295/3. On Thurot see Scots Magazine 22 (February 1760), 99-104.

9 J.R. Western, The English Militia in the Eighteenth Century: The Story of a Political Issue. 1660-1802 (London, 1965), chap. 7.

${ }^{10}$ Garrick to the earl of Bute, 10 July 1756, in The Letters of David Garrick, eds. David M. Little and George M. Kahrl, (Cambridge, Mass., 1963), I, 246. 
11 John Home to Gilbert Elliot, [August 1757], National Library of Scotland, Minto MSS, EFP 9.

12 The Dramatic Execution of Agis (London, 1758). See Alexander Carlyle's defense of the play in the Critical Review 5 (January-June 1758), 233-42.

${ }_{13}$ Ernest Cambell Mossner, The Forgotten Hume: Le Bon David (New York, 1943), chap. 4.

${ }^{14}$ Allan Sinclair, "The Authenticity of the Poems of Ossian," The Celtic Magazine 5 (June 1880), 311-18.

15 Unless otherwise noted, information about the role of the Edinburgh literati in the Ossian affair is drawn from the testimonies of Blair, Home, Carlyle, and Ferguson published in the Appendix to the Report of the Committee of the Highland Society of Scotland, Appointed to Inquire into the Nature and Authenticity of the Poems of Ossian, ed. Henry Mackenzie (Edinburgh, 1805). On George Laurie see Henry Grey Graham, Scottish Men of Letters in the Eighteenth Century (London, 1908), pp. 226-28.

${ }^{16}$ Home to Bute, [26] August 1759, Bute MSS, Mount Stuart, Isle of Bute, box 2 (1759), no. 147. After continuing in this vein several sentences longer, Home adds: "I should make an apology for this declamation, but it is the subject nearest to my heart." I am grateful to the Marquess of Bute and his archivist, Miss Catherine Armet, for permission to examine and cite the Bute manuscripts.

17 Ferguson to Elliot, 14 September 1759, National Library of Scotland, Minto MSS, EFP 14, fols. 9-10.

${ }^{18}$ More generally, it has been argued that Macpherson consciously borrowed from Hector Boece "the precedent for setting an idealized ancient society against a disappointing modern one." Matthew P. MacDiarmid, "Ossian as Scottish Epic," Scottish Literary News 3 (November 1973), 7.

19 Blair to Hume, 29 September 1763, in John Hill Burton, Life and Correspondence of David Hume, 2 vols. (New York, 1967), I, 468.

${ }^{20}$ Although Blair's recollections about Macpherson's reluctance to publish a book of Ossianic fragments were recorded thirty-seven years later, their accuracy is indirectly confirmed by Macpherson's letter to George Laurie of 18 March 1760 in Yale University Library, C1870. I am grateful to N.T. Phillipson for bringing this item to my attention and to Yale University and McGraw-Hill Book Company for permission to cite it.

${ }^{21}$ James Macpherson, Preface to the Fourth Edition of Fingal (1773), in Poems of Ossian, I, p. lxvii.

${ }^{22}$ The name Fingal, rather than the traditional Finn (or Finn mac Cumail), was apparently invented by Macpherson. For our purposes, a more significant alteration was his substitution of western Scotland for Ireland as the site of Finn or Fingal's domain. See Macbain, "Macpherson's Ossian," p. 145, and Nutt, Ossian, p. 49.

${ }^{23}$ The figure of $£ 100$ comes from a letter from Mrs. Montagu to Lord Lyttelton, 31 October 1760, in The Letters of Mrs. Elizabeth Montagu, (London, 1809-13), IV, p. 320. There is much information about the Ossianic collection in Robert Hay Carnie, "Macpherson's Fragments of Ancient Poetry and Lord Hailes," English Studies 41 (1960), 17-26, which demonstrates extensive involvement by the Edinburgh legal community in response to Blair's call for financial help. I disagree, however, with Professor Carnie's contention that Macpherson's letter to Blair of 16 June 1760 expressing willingness to head for the Highlands if money could be raised for that purpose (ibid., p. 23) seems to invalidate Blair's testimony about Macpherson's reluctant attitude (ibid., p. 24), for in the first place the letter in question may be read as yet another stalling tactic, and in the second place it apparently was written after the dinner party at which Macpherson was finally won over by the Edinburgh literati.

${ }^{24}$ Blair to David Dalrymple, Lord Hailes, 23 June 1760, in Carnie, "Macpherson's Fragments," p. 22. Emphasis added.

${ }^{25}$ Blair to Hume, 29 September 1763, in Burton, Life and Correspondence of David Hume, I, 469.

${ }^{26}$ Carlyle and Ferguson both defended the liberties taken by Macpherson on the grounds that similar liberties had probably been taken by Homer.

27 The theme of national defense against fearsome Norse oversea-raiders, or Lochlannach, was an authentic part of the Ossianic tradition since the Middle Ages (Nutt, Ossian, pp. 10, 39), but Macpherson added embellishments, such as introducing Roman as well as Norse invaders. Smart, James Macpherson, pp. 104-5.

${ }^{28}$ Alexander Carlyle, Anecdotes and Characters of the Times, ed. James Kinsley (London, 1973), p. 76. 
29 Although the title page of Fingal says 1762 , the actual time of publication was December 1761. The Poker Club was presumably being organized at around the same time and came into existence at the beginning of 1762 .

30 "Minutes of the Poker Club, 1774-1784" and "Poker Club Attendance Analysis" (by Jeremy Cater), Edinburgh Univ. Library, Dc. 5.126 and Dc. 5.126*; Carlyle, Anecdotes and Characters, p. 215.

${ }^{31}$ James Boswell, The Life of Samuel Johnson, 2 vols. (London, 1927), I, 548; Walpole to William Mason, 22 April 1782, in The Yale Edition of Horace Walpole's Correspondence, ed. W.S. Lewis (New Haven, 1937-73), II, 239-40.

${ }^{32}$ Macpherson's admiration for the members of the Ossianic "cabal" remained strong until his death in 1796. His will bequeathed $£ 2000$ to John Home as a special sign of gratitude and affection. Alice Edna Gipson, John Home: A Study of His Works (Caldwell, Idaho, 1917), p. 26. 